\title{
FAKTOR KOREKSI VOLUME DÖLOK YANG DIUKUR DI SUNGAI (LOGPOND) (Correction factor of logs volume measured in logpond)
}

\author{
Oleh/By \\ Wesman Endom \& Sukanda
}

Summary

\begin{abstract}
Measuring the volume of logs which have been rafted on the rivers is very difficult. The difficulty is mostly in measuring the average top and bottom diameters of logs because the largest portion of logs are inside the water.

In this paper, the xesults of measurements carried out both on the ground and in the river are described. Lately, log measurement in the river is necessary because :

a. Volume of logs sent to industries would be measured in the river.

b. Many logs of the illegal cutting found are rafted in the river.

The observation reveals that :

1. Volumes of logs measured on the ground and in the river are significantly different.

2. From the sample of 60 logs of Dryobalanops spp. it is found that the total volume mecusured on the ground is $273,18 \mathrm{m3}$, while the total volume measured in the river is $262,76 \mathrm{~m}^{3}$. The total difference is $10,42 \mathrm{~m}^{3}$ or $0,04 \mathrm{~m}^{3}$ per $\mathrm{m}^{3}$ in average.

3. The correction factor (FK) then is $0,04 \mathrm{m3}$ per $\mathrm{m} 3$ or $3,81 \%$. It means that the volume of log measured in the river is smaller than the volume measured on the ground. Therefore, the volume measured in the river should be multiplied with the correction factor of 1.04 to obtain the real volume as measured on the ground.
\end{abstract}

\section{PENDAHULUAN}

Pola pembangunan nasional berkesinambungan yang berwawasan lingkungan merupakan sistem yang harus menjadi acuan dalam memanfaatkan sumberdaya alam secara maksimal dan berhasil guna.

Bagi kehutanan, prinsip tadi perlu diterapkan dalam pengertian antara lain bahwa setiap kayu yang ditebang secara tertib harus tercatat jenis volumenya. Selain itu selayaknya diketahui dari mana asalnya.

Akhir-akhir ini dengan semakin banyaknya prasarana jalan angkutan (darat dan sungai) berikut sarana angkutan dan adanya tempat pengolahan kayu, kegiatan penebangan hutan liar disinyalir cenderung semakin meningkat. Ini banyak terjadi seperti dilaporkan berbagai masmedia, di mana sering ditemukan dolok tanpa dokumen syah yang sudah dalam bentuk rakit yang panjang di sungai, seperti di Riau, Kalimantan Barát, Sumatera Selatan, dan sebagainya. Kasus semacam ini setiap tahun terus berlangsung, terutama pada musim tertenti yang dikenal dengan istilah "banjir kap".

Dengan banyaknya kasus seperti disebutkan diatas, proses pembuatan berita acara pemeriksaan (BAP) yang menerangkan tempat kejadian ditemukkan, banyaknya volume kayu dan jenisnya dalam suatu patroli pengamanan hutan, hendaknya segera dibuat ditempat, dan dilaporkan kepada yang berwenang untuk diambil tindak lanjutnya.

Untuk mengetahui jumlah kayu temuan tersebut di sungai, bukanlah suatu pekerjaan yang mudah. Kesulitan ini terjadi disebabkan pengukurannya tidak semudah seperti dilakukan di darat, terutama pengukuran diameter batang rata-rata baik pada pangkal maupun ujungnya karena sebagian batang kayu berada di dalam air.

Di samping itu tidak mustahil bahwa dolok dari suatu pengusahaan hutan dan telah berada di sungai/ logpond juga belum termasuk di dalam daftar Laporan Hasil Penebangan (LHP). Ini tentu sangat merugikan pemerintah, karena di samping dapat mengurangi pendapatan negara, juga menyulitkan pelaksanaan pengawasan penerapan TPTI yang dilakukan, khususnya untuk mengetahui lokasi atau daerah di mana dilakukan tebangan dan besar intensitas tebangannya.

Berkaitan dengan masalah 'itu, serta menyangkut pula pada besarnya pendapatan negara, maka pengukuran penentuati isi kayu merupakan bagian kegiatan yang penting, karena uptuk dunia perdagangan harga dolok tergantung pada isi dan kualitasnya. Oleh karena 
itu ketelitian dan kepraktisan pengukuran isi kayu besar peranannya (Harianto, .1979).

Dalam studi ini dicoba dikaji hasil pengukuran volume dolok di sungai yang akhir-akhir ini sangat diperlukan, karena :

a. Banyak kayu yang dikirim ke industri secara teknis adalah sebesar seperti yang telạh berada 'di sungai/logponds;

b. Banyak dolok tidak bertuan yang ditemukan sudah dalam bentuk rakit di sungai

Dari penelitian ini diperoleh gambaran perbandingan hasil pengukuran isi dolok yang dilakukan di darat dengan di sungai, yang juga perlu untuk pemantauan pengawasan produksi kayu khususnya yang bersifat ilegal yang telah berada di sungai. Untuk itu dalam makalah ini disajikan :

1. Kajian tentang cara pengukuran kayu di sungai; dan

2. Perhitungan besarnya tingkat perbedaan antara hasil pengukuran isi kayu di logyard dan di logpond serta besaran faktor koreksinya.

\section{METODE PENELITIAN}

Banyaknya dolok yang diambil sebagai sampel dalam pengukuran ini berjumlah 60 buah seluruhnya berasal dari jenis kayu Dryobalanops spp. Keseluruhan dolok tersebut diukur sewaktu masih di darat dan pada saat menjadi rakit di sungai.

Peralatan dan bahan yang dipergunakan terdiri atas :

a. Rol meter dengan panjang $20 \mathrm{~m}$ untuk mengukur panjang

b. Tongkat ukur untuk mengukur diameter dolok

c. Daftar isian untuk mencatat hasil pengukuran

d. Tabel volume untuk menghitung volume dolok

e. Kapur/cranyon untuk pembuatan nomor dolok

Pengukuran dolok di darat adalah sebagai berikut :

a. Persiapan mencakup pengadaan alat ukur dan bahanbahan yang akan dipergunakan selama pengukuran

b. Pemberian nomor/tanda pada bagian pangkal, ujuing dan pada batang dolok, untuk memudahkan identifikasi pengukuran dolok yang sama

c. Pengukuran panjang dan diameter dolok (panigkal dan ujung masing-masing dua kali secara bersilangan tegak lurus) dalam satuàn $\mathrm{cm}$ penuh.

d. Dolok yang telah selesai diukur diceburkan ke sungai

Dolok yang telah diceburkan ke dalam sungai, disusun menjadi sebuah rakit, lalu masing-masing dolok diukur kembali panjangnya dan diameter pangkal dan ujungnya sama seperti pada pengukuran di darat, dan dicatat pada daftar isian yang tersedia sesuai deagan nomor yang ada.

Perhitungan volume setiap dolok baik untuk pengukuran di darat maupun di sungai dilakukan dengan mempergunakan rumus Smalian (Husch, 1963) sebagai berikut :

$$
V d=\frac{(B d u+B d p)}{2} \times
$$

dimana

Vd $=$ Volume dolok dalam $\mathrm{m}^{3} ; \mathrm{Bdu}=$ Bidang dasar dolok bagian ujung dalam $\dot{\mathrm{m}}^{2} ; \mathrm{Bdp}=$ Bidang dasar dolok bagian pangkal dalam $\mathrm{m}^{2}$ dan $\mathrm{p}=$ panjans dolok dalam $\mathbf{m}$.

Dari kedua cara pangukuran tersebut diperoleh Faktor Koreksi (FK) dengan cara membandingkan selisih antara volume yang didapat sebagai hasil pengukuran dolok di darat dan di sungai dengan volume dolok di darat, lalu dikalikan dengan $100 \%$. Secara sederhana perumusannya dapat dituliskan . sebagai berikut :

$F K=\frac{(V d-V s)}{V d}$

di mana

$V d=$ Volume dolok di darat $\left(m^{3}\right)$ dan

$\mathrm{Vs} \doteq$ volume dolok di air $\left(\mathrm{m}^{3}\right)$

Selanjutnya untuk mengetahui ada tidaknya perbedaan hasil pengukuran dolok di darat dan di sungai, dilakukan analisis statistik dengan metoda uji t.

\section{HASIL DAN PEMBAHASAN}

Hasil pengukuran dari ke 60 dolok yang dijadikan sebagai sampel yang diambil di PT. Kayu Mahakam disajikan pada Tabel 1. 
Tabel 1. Hasil pengukuran 60 contoh dolok dari jenis kayu Dryobalanops spp. di darat dan sungai

Table 1. Measurement results of 60 logs Dryobalanops spp. measured on the ground and in the river.

\begin{tabular}{|c|c|c|c|c|c|c|c|c|c|c|c|c|c|c|c|c|}
\hline \multirow{4}{*}{ No } & \multicolumn{7}{|c|}{ Di darat (Logyard) } & \multicolumn{7}{|c|}{ Di sungai (Logpond) } & \multirow{4}{*}{$\begin{array}{l}\text { Selisih } \\
\text { (Difference) } \\
\mathrm{D}=(\mathrm{x} 1-\mathrm{x} 2)\end{array}$} & \multirow{4}{*}{$\mathrm{D}^{2}$} \\
\hline & \multicolumn{4}{|c|}{ Diameter $(\mathrm{cm})$} & \multirow[b]{3}{*}{$\overline{\mathrm{d}}$} & \multirow{3}{*}{$\begin{array}{c}\text { Panjang } \\
\text { (Length) } \\
\text { (m) }\end{array}$} & \multirow{3}{*}{$\begin{array}{c}\text { Volume } \\
(\mathrm{x} 1) \\
\left(\mathrm{m}^{3}\right)\end{array}$} & \multicolumn{4}{|c|}{ Diameter $(\mathrm{cm})$} & \multirow[b]{3}{*}{$\mathrm{d}$} & \multirow{3}{*}{$\begin{array}{c}\text { Panjang } \\
\text { (Length) } \\
\text { (m) }\end{array}$} & \multirow{3}{*}{$\begin{array}{l}\text { Volume } \\
(\mathrm{x} 2) \\
\left(\mathrm{n}^{3}\right)\end{array}$} & & \\
\hline & $\begin{array}{l}\text { Par } \\
(\mathrm{Bot}\end{array}$ & $\begin{array}{l}\text { gkal } \\
\text { om })\end{array}$ & & & & & & \multicolumn{2}{|c|}{$\begin{array}{l}\text { Pangkal } \\
\text { (Bottom) }\end{array}$} & \multicolumn{2}{|c|}{$\begin{array}{l}\text { Ujung. } \\
\text { (Top). }\end{array}$} & & & & & \\
\hline & $\overline{\mathrm{d} 1}$ & $\overline{d 2}$ & $\overline{d 3}$ & $\bar{d} 4$ & & & & $\mathrm{~d} 1$ & $\mathrm{~d} 2$ & $\mathrm{~d} 3$ & $\mathrm{~d} 4$ & & & & & \\
\hline 1 & 2 &, 3 & 4 & 5 & 6 & .7 & 8 & 9 & 10 & 11 & 12 & 13 & 14 & 15 & 16 & 17 \\
\hline 1 & 89 & 76 & 61 & 62 & 72 & 11,90 & 4,85 & 88 & 72 & 60 & 62 & 70 & 11,90 & 4,58 & 0,27 . & 0,0729 \\
\hline 2 & 76 & 80 & 70 & 73 & 75 & 14,70 & 6,49 & 74 & 80 & 70 & 72 & 74 & 14,70 & 6,32 & 0,17 & 0,0289 \\
\hline 3 & 84 & 88 & 75 & 71 & 79 & $13,2 \mathrm{C}$ & 6,47 & 80 & 89 & 70 & 70 & 78 & 13,20 & 6,31 & 0,16 & 0,0256 \\
\hline 4 & 90 & 94 & 78 & 82 & 86 & 10,10 & 5,87 & 92 & 92 & 78 & 81 & 85 & 10,10 & 5,73 & 0,14 & 0,0196 \\
\hline 5 & 78 & 69 & 60 & 58 & 66 & 10,60 & 3,63 & 76 & 68 & 57 & 58 & 65 & 10,60 & $3,41^{\circ}$ & 0,22 & $.0,0484$ \\
\hline 6 & 85 & 80 & 68 & 78 & 77 & 11,90 & 5,54 & 86 & 80 & 68 & 72 & 76 & 11,90 & 5,40 & 0,14 & 0,0196 \\
\hline$?$ & 67 & 75 & 53 & 51 & 61 & 17,60 & 5 , & 76 & 62 & 55 & 51 & 60 & 17,60 & 4,98 & 0,16 & 0,0256 \\
\hline 8 & 74 & 68 & 59 & 53 & 63 & 12,80 & 3,99 & 72 & 68 & 58 & 53 & 62 & 12,80 & 3,86 & 0,13 & 0,0169 \\
\hline 9 & 76 & 72 & 70 & 70 & 72 & 9,10 & 3,71 & 74 & 72 & 70 & 70 & 71 & 9,10 & 3,60 & 0,11 & 0,0121 \\
\hline 10 & 74 & 76 & 65 & 67 & 71 & 8,60 & 3,40 & 82 & 76 & 62 & 58 & 69 & 8,60 & 3,22 & 0,18 & 0,0324 \\
\hline 11 & 98 & 87 & 77 & 80 & 85 & 8,90 & 5,05 & 95 & 86 & 80 & 76 & 84 & 8,90 & 4,93 & 0,12 & 0,0144 \\
\hline 12 & 68 & 64 & 54 & 58 & 61 & 10,30 & 3,01 & 65 & 69 & 58 & 53 & 60 & 10,30 & 2,91 & 0,10 & 0,0100 \\
\hline 13 & 69 & 72 & 52 & 50 & 61 & 11,30 & 3,30 & 70 & 69 & 50 & 50 & 60 & 11,30 & 3,20 & 0,10 & 0,0100 \\
\hline 14 & 72 & 59 & 58 & 57 & 62 & 10,20 & 3,08 & 60 & 68 & 58 & 57 & 60 & 10,20 & 2,88 & 0,20 & 0,0400 \\
\hline 15 & 68 & 65 & 54 & 58 & 61 & 10,00 & 2,92 & $68^{\circ}$ & 63 & 54 & 56 & 60 & 10,00 & 2,83 & 0,09 & 0,0081 \\
\hline 16 & 83 & 84 & 71 & 68 & 74 & 11,90 & 5,12 & 92 & 83 & 62 & 55 & 73 & 11,90 & 4,98 & 0,14 & 0,0196 \\
\hline 17 & 98 & 92 & $76^{\circ}$ & 78 & 86 & 1 & 3 & 98 & 89 & 76 & 74 & 84 & 10,90 & 6,04 & 0,29 & 0,0841 \\
\hline 18 & 76 & 75 & 69 & 66 & 71 & 11,00 & 4,36 & 76 & 75 & 68 & 64 & 70 & 11,00 & 4,23 & 0,13 & 0,0169 \\
\hline 19 & 97 & 96 & 74 & 72 & 85 & 13,30 & 7,55 & 98 & 95 & 74 & 72 & 84 & 0 & 7 & 0,18 & 0,0324 \\
\hline 20 & 73 & 70 & 60 & 59. & 66 & 9,80 & 5 & 74 & 69 & 58 & 57 & 64 & 9,80 & 3,15 & 0,20 & 0,0400 \\
\hline 21 & 95 & 87 & 82 & 76 & 85 & 9,90 & 5,62 & 88 & 90 & 78 & 80 & 84 & 9,90 & 5,49 & 0,13 & 0,0169 \\
\hline 22 & 90 & 89 & 84 & 78 & 85 & 8,40 & 4,77 & 90 & 87 & 78 & 79 & 84 & 8,40 & 4,66 & 0,11 & 0,0121 \\
\hline 23 & 83 & 86 & 62 & 65 & 74 & 9,20 & 3,96 & 84 & 80 & 67 & 61 & 73 & 9,20 & 3,85 & 0,11 & 0,0121 \\
\hline 24 & 75 & 73 & 63 & 66 & 70 & 10,90 & 4,19 & 75 & 73 & 66 & 63 & 69 & 10,90 & 4,08 & 0,11 & 0,0121 \\
\hline 25 & 70 & 65 & 59 & 55 & 62 & 11,80 & 3,86 & 70 & 64 & 55 & $58:$ & 61 & 11,80 & 3,45 . & 0,11 & 0,0121 \\
\hline 26 & 76 & 64 & 56 & 55 & 62 & 7,20 & 2,24 & 74 & 62 & 56 & 55 & 61 & 7,20 & 2,10 & 0,14 & 0,0196 \\
\hline 27 & 85 & 82 & 73 & 68 & 76 & 11,50 & 5,21 & 82 & 80 & 76 & 74 & 75 & 11,50 & 5,08 & 0,13 & 0,0169 \\
\hline 28 & 75 & 67 & 66 & 64 & 68 & 15,90 & 7 & 72 & 61 & 67 & 64 & 66 & 15,90 & 5,44 & 0,33 & 0,1089 \\
\hline 29 & 83 & 75 & 70 & 71 & 74 & 10,10 & 4,34 & 80 & 73 & 70 & 71 & 73 & 10,10 & 4,23 & 0,11 & 0,0121 \\
\hline 30 & 79 & 76 & 69 & 68 & 72 & 10,30 & 4,19 & 78 & 72 & 69 & 67 & 71 & 10,30 & 4,08 & 0,11 & 0,0121 \\
\hline 31 & 76 & 79 & $65^{\circ}$ & 62 & 69 & 9,20 & 3,44 & 75 & 76 & 64 & 62 & 67 & 9,20 & 3,24 & 0,20 & 0,0400 \\
\hline 32 & 70 & 67 & 66 & 65 & 67 & 9,10 & 3,38 & 68 & 67 & 65 & 63 & 66 & 9,10 & 3,28 & 0,10 & 0,0100 \\
\hline 33 & 74 & 72 & 60 & 58 & 66 & 12,90 & 4,41 & 74 & 72 & 58 & 57 & 65 & 12,90 & 4,28 & 0,13 & 0,0169 \\
\hline 34 & 79 & 81 & 68 & 67 & 73 & 9,70 & 4,06 & 77 & 79 & 67 & 67 & 71 & 9,20 & 3,84 & 0,22 & 0,0484 \\
\hline 35 & 83 & 71 & 62 & 60 & 68 & 10,10 . & 3,67 & 78 & 69 & 60 & 59 & 67 & 10,10 & 3,53 & 0,14 & 0,0196 \\
\hline 36 & 76 & 75 & 73 & 69 & 72 & 10,60 & 4,32 & 76 & 72 & 70 & 68 & 71 & 10,60 & 4,20 & 0,12 . & 0,0144 \\
\hline 37 & 87 & 81 & 70 & 68 & 74 & 17,10 & 7,76 & 65 & 80 & 71 & 6.7 & 75 & 17,10 & 7,55 & 0,21 & 0,0441 \\
\hline 38 & 84 & 87 & 77 & 73 & 80 & 9,10 & 4,57 & 87 & 82 & 75 & 72 & 78 & 9,10 & 4,35 & 0,22 & 0,0484 \\
\hline 39 & 85 & 79 & 69 & 66 & 75 & 14,10 & 6,23 & 81 & 78 & 68 & 65 & 73 & 14,10 & 5,90 & 0,33 & 0,1089 \\
\hline 40 & 79 & 76 & 68 & 65 & 72 & 9,60 & 3,91 & 76 & 73 & 64 & 65 & 69 & 9,60 & 3,59 & 0,32 . & $.0,1024$ \\
\hline
\end{tabular}




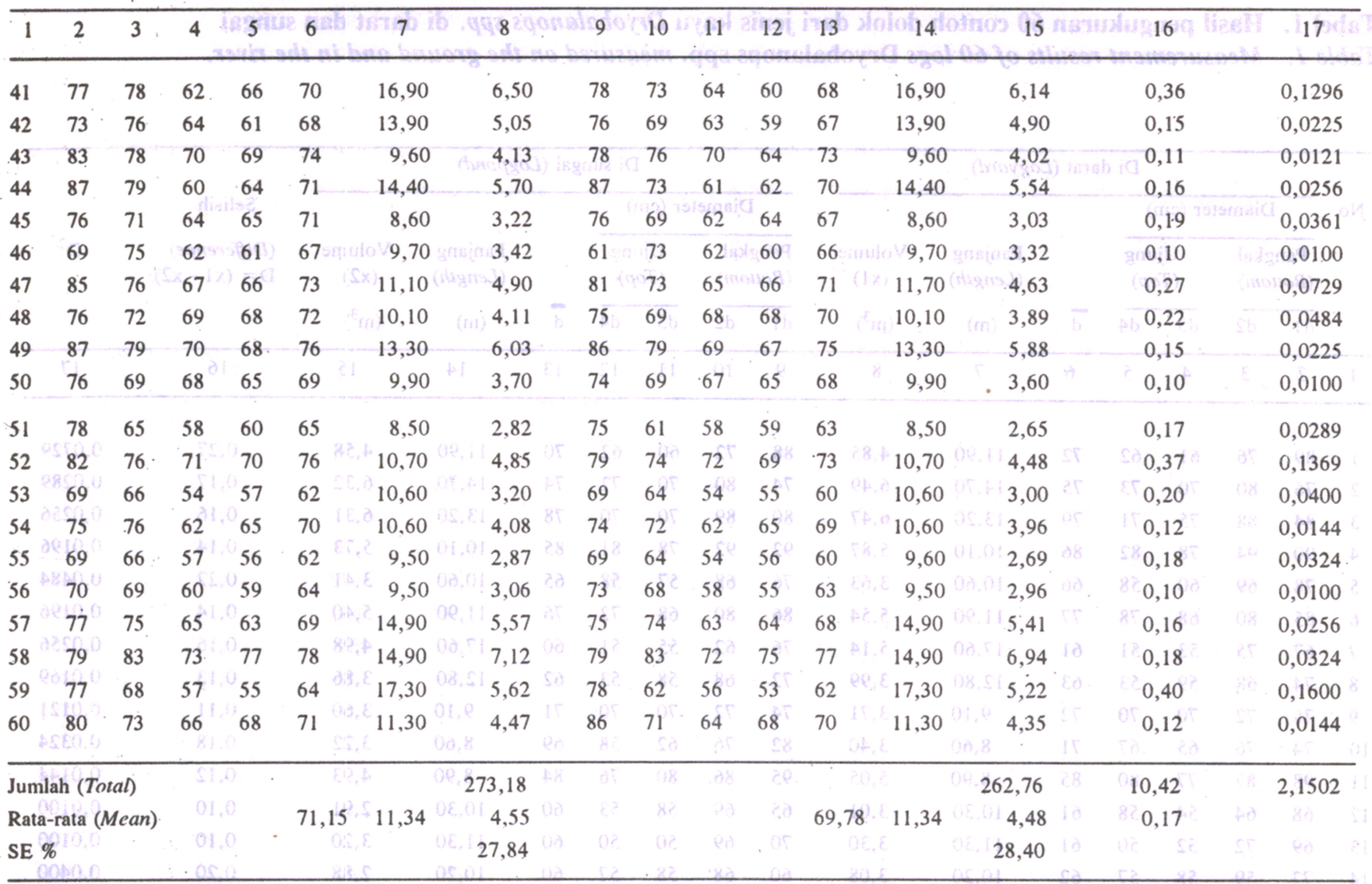

Tabel 1 memperlihatkan bahwa hasil pengukuran rata-rata panjang dari ke 60 dolok yang diukur baik di darat maupun di sungai memiliki nilai yang sama. Akan tetapi lain halnya untuk rata-rata diameter dolok, hasil yang diperoleh menunjukkan adanya perubahan dari rata-rata sebesar $71,2 \mathrm{~cm}$ di darat menjadi rata-rata $69,8 \mathrm{~cm}$ di sungai (beda $1,4 \mathrm{~cm}$ ).

Selanjutnya untuk mengetahui apakah hasil pengukuran volume dolok yang dilakukan di darat dan di sungai memberikan adanya perbedaan atau tidak, hasil uji $\mathbf{t}$ yang dilakukan menunjukkan bahwa ternyata $\mathrm{t}$ hitung $=17,7064$, sedangkan $\mathrm{t}$ tabel $=2,01$ ( $\mathrm{t}$ hitung lebih besar dari $t$ tabel). Ini berarti adanya perbedaan hasil pengukuran volume dolok yang dilakukan di darat dan di sungai. Hasil pengukuran volume di sungai ternyata lebih rendah dari hasil pengukuran di darat. Adapun besarnya perbedaan tersebut adalah sebesar : $10,42 \mathrm{~m}^{3} / 273,18 \mathrm{~m}^{3}=0,038$ atau sebesar $3,8 \%$

Sebagaimana telah disebutkan di atas bahwa analisis yang dilakukan dengan uji $t$ memberikan gambaran hasil pengukuran volume dolok yang dilakukan di darat dạn di sungai berbeda nyata. Adanya perbedaả ini terjadi karena adanya perbedaan hasil pengukuran diameter pada pangkal dan ujung dolok yang memang dirasakan kesulitannya sewaktu pengukuran tersebut dilakukan disungai. Kesulitan tersebut disebabkan oleh sebagian diameter dolok terendam di dalam air, sehingga tidak dapat dipastikan dengan tepat apakah pengukuran diameter itu cukup memadai atau mewakili besar diameter rata-rata serta apakah posisi pengukuran diameter dolok dilakukan secara menyilang tegak lurus atau belum. Dari hasil pengukuran pada sejumlah 60 buah dolok yang telah dilakukan didapat gambaran tentang besarnya. selisih pengukuran diameter dolok di darat dan di sungai yang diperoleh adalah sebesar $\pm 1,4 \mathrm{~cm}$. Perbedaan inilah yang kemudian menyebabkan adanya perbedaan besarnya volume sebagaimana telah dijelaskan terdahulu.

Oleh karena volume kayu hasil pengukuran di sungai lebih kecil dari hasil pengukuran di darat maka untuk memperoleh volume dolok sebenarnya, volume hasil pengukuran di sungai perlu dikoreksi yang besar nilai koreksinya sebesar 1,04 . Artinya hasil pengukuran volume dolok dalam rakit di sungai perlu dikalikan 
dengan 1,04 agar diperoleh volume yang sebenarnya.

\section{KESIMPULAN}

1. Isi kayu hasil pengukuran di darat dan di sungai menunjukkan perbedaan nyata untuk tingkat kepercayaan $95 \%$.

2. Dari contoh 60 dolok jenis kayu Dryobalanops spp. hasil pengamatan memberikan hasil bahwa jumlah isi kayu yang diukur di darat sebanyak $273,18 \mathrm{~m}^{3}$, sedangkan untuk di sungai volumenya lebih kecil. yaitu sebesar $262,76 \mathrm{~m}^{3}$. Perbedaan volume kayu kedua cara pengukuran sebesar $10,42 \mathrm{~m}^{3}$ atau dengán rataan berbeda $0,04 \mathrm{~m}^{3}$ untuk setiap $\mathrm{m}^{3}$ yang diukur di sungai.

3. Berdasarkan besaran adanya perbedaan ini, maka dapat dihitung Faktor Koreksi (FK) sebesar $0,04 \mathrm{~m}^{3}$ per $\mathrm{m}^{3}$ atan $3,81 \%$. Berarti dalam setiap pengukuran volume dolok di sungai perlu dikalikan dengan FK sebesar 1,04 agar nilainya kurang lebih sama dengan hasil pengukuran volume dolok di darat.

4. Pengkaiian nenelitian serupa secara lebih mendalam terutama untuk jenis kayu lainnya perlu dilakukan, mengingat lebih banyak lagi jenis kayu yang sudah dapat dimanfaatkan dewasa ini.

\section{DAFTAR PUSTAKA}

Harianto. 1979. Beberapa Cara Pengukuran Kayu. Yayasan Pembinaan Fakultas Kehutanan Universitas Gadjah Mada, Yogyakarta.

Husch, B. 1963. Forest Mensuration and Statistics. The Ronald Press Company. New York. 


\section{BIODATA PENULIS}

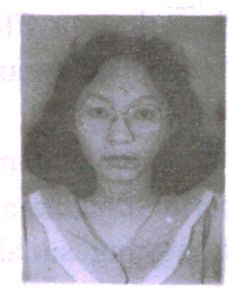

Efrida Basri

Lahir di Bukittinggi tanggal 24 Pebruari 1958

Lulus Sariana Fakultas Kehutanan IPB tahun 1982. Mulai bekerja di Pusat Litbang

Hasil Hutan tahun 1982, sejak tảhun 1989 menjabat sebagai Ajun Peneliti Muda.

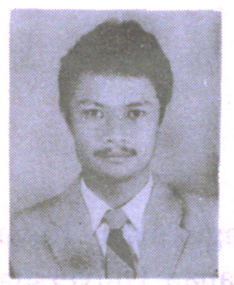

Syarif Hidayat

Lahir di Garut tanggal 11 Oktober 1958

Lulus Sarjana Fakultas Kehutanan IPB tahun 1981, lulus S2 Forestry School, University of Canterbury, New Zealand tahun 1990. Mulai bekerja di Pusat Litbang Hasil Hutan sejak tahun 1982, sekarang menjabat sebagai Asisten Peneliti Muda.

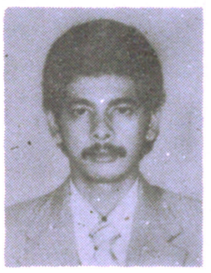

Jamal Balfas

Lahir di Bogor pada tanggal 4 Juni 1958

Lulus Fakultas Kehutanan IPB tahun 1983, dan Master of Science (S2) di Australian National University, Canberra, tahun 1993. Bekerja di Pusat Litbang Hasil Hutan sejak tahun 1984 dan menjadi Ajun Peneliti Muda dengan spesialisasi Teknologi. Kayu .

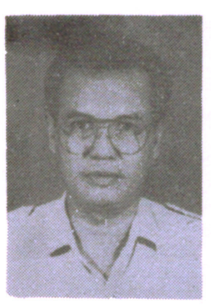

Sasa Abdurrohim

Lahir di Cicalengka tanggal 5 Januari 1945.

Lulus Fakultas Kehutanan IPB tahun 1973 dalam keahlian Teknologi Kayu dan S2 IPB jurusan Ilmu Perkayuan Tahun 1981. Bekerja di Pusat Litbang Hasil Hutan mulai tahun 1973 dalam penelitian pengawetan kayu. Bulan Agustus 1985 sampai Januari 1991 diberi tugas menyiapkan pembentukan Balai Penelitian Kehutanan Manokwari merangkap sebagai Ajun Peneliti Madya pada. Pusat Lithang Hasil Hutan. Sejak Bulan April 1990 diangkat menjadi Peneliti Muda pada Pusat Litbang Hasil Hutan.

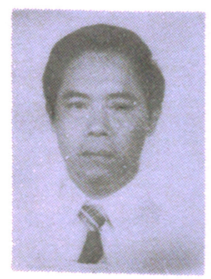

Barly

Lahir di Bogor tanggal 23 Desember 1947

Lulus Akademi Kimia Analis tahun 1976, Fakultas Hukum Universitas Ibn Khaldun 1981.

Bekerja pada Pusat Litbang Hasil Hutan sejak tanggal 1 Desember 1967, tahun 19821983 menjabat sebagai Kepala Laboratorium BPHH, 1984 - 1988 sebagai Kepala Urusan Sarana Penelitian P3HH, tanggal 1 Desember 1985 sebagai Asisten Peneliti Muda, dan sejak tanggal 1 Januari 1990 hingga sekarang menjadi Ajun Peneliti Madya, dengan spesialisasi Pengawetan Kayu.

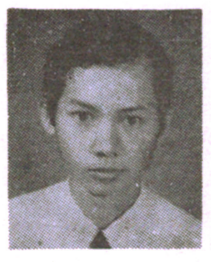

Hariyatno Dwiprabowo

Lahir di Semarang tanggal 30 Mei 1950.

Lulus Fakultas Kehutanan IPB tahun 1976, S2 dan S3 dari North Carolina State University, AS, dengan spesialisasi Operations Research.

Bekerja di Pusat Litbang Hasil Hutan sejak tahun 1977, sejak tahun 1989 menjadi Ajun Peneliti Madya dengan spesialisasi Ekonomi Kehutanan. 

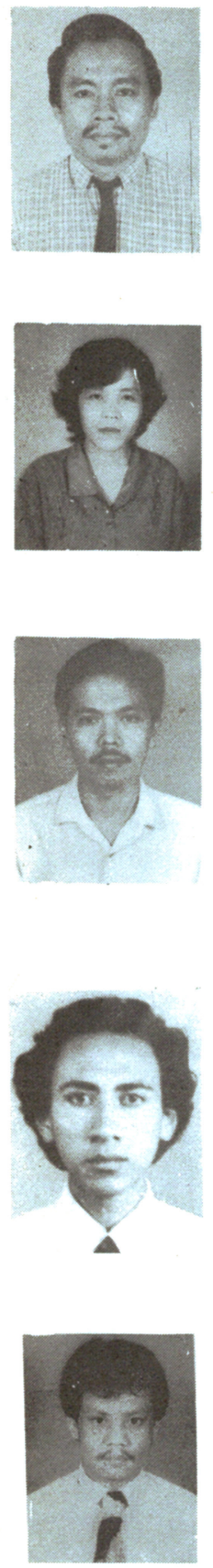

O. K. Karyono

Lahir di Ciamis tanggal 7 Maret 1950

Lulus Fakultas Ekonomi Universitas Pakuan Bogor tahun 1990. Bekerja di Pusat Litbang Hasil Hutan sejak tahun 1970 sebagai staf peneliti pada kelompok peneliti Ekonomi Kehutanan.

\section{Sona Suhartana}

Lahir di Tasikmalaya tanggal 12 Oktober 1960

Lulus Fakultas Kehutanan IPB tanggal 2 Maret 1985.

Bekerja di Pusat Litbang Hasil Hutan sejak tahun 1985, sejak 1 Agustus 1992 menjadi Asisten Peneliti Madya dengan spesialisasi Eksploitasi Hutan.

\section{Rachman Effendi}

Lahir di Bogor tanggal 10 Oktober 1957

Lulus Sarjana Fakultas Pertanian IPB tahun 1981, Lulus S2 University Pertanian Malaysia. Mulai bekerja di Pusat Litbang Hasil Hutan sejak tahun 1982, sekarang menjabat sebagai Ajun Peneliti Muda dengan spesialisasi Ekonomi Kehutanan.

\section{Wesman Endom \\ Lahir di Subang tanggal 27 Maret 1954}

Lulus Akademi Ilmu Kehutanan Bandung tahun 1977, Kursus Penginderaan Jauh di Pusdik UGM 1982, dan Kursus Survey Hutan di SHPPU Badan Intag dan IPB 1984, Kursus Forest Survey di ITC, Nederland 1986/1987, dengan spesialisasi Eksploitasi Hutan. Bekerja di Pusat Litbang Hasil Hutan sebagai Ajun Peneliti Muda hingga sekarang.

\section{Sukanda}

Lahir di Cirebon tanggal 19 Mei 1954

Lulus Fakultas Kehutanan Universitas Mulawarman pada tahun 1982.

Bekerja di Pusat Litbang Hasil Hutan sejak tahun 1983 sebagai Staf Peneliti hingga sekarang, dengan spesialisasi Eksploitasi Hutan. 


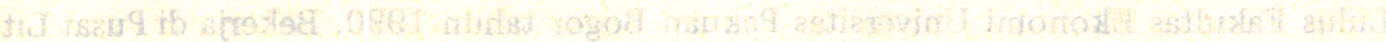

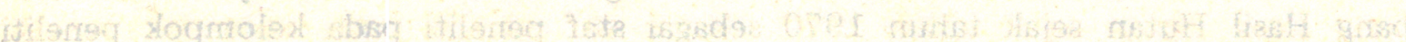

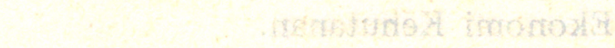

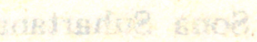

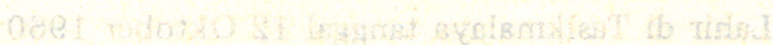

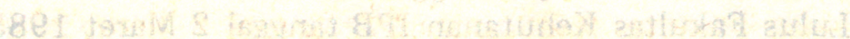

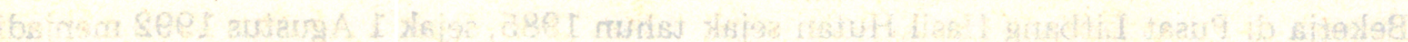

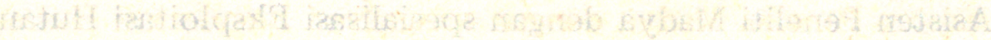

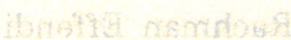

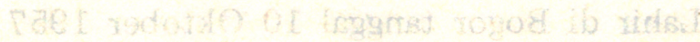

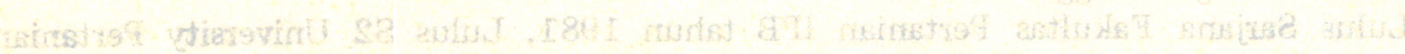

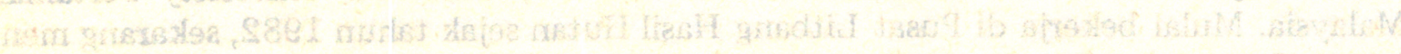

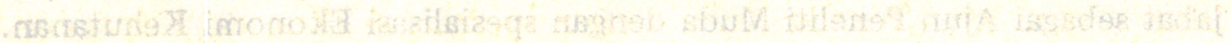

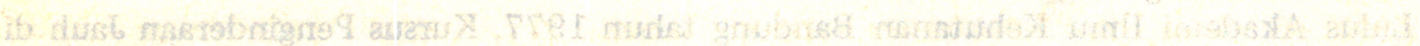

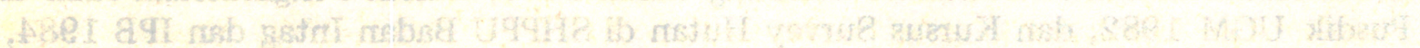

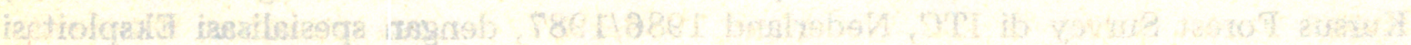

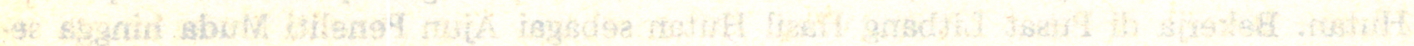

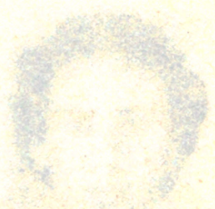

shomalats
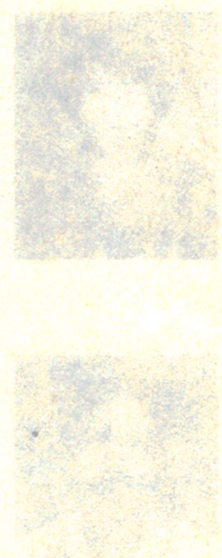

-

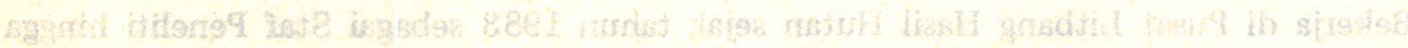

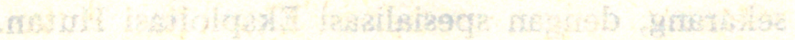

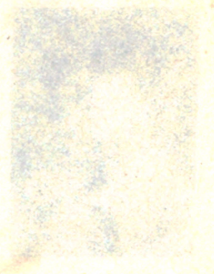




\section{PETUNJUK BAGI PENULIS}

$\boldsymbol{B} \boldsymbol{A} \boldsymbol{H} \boldsymbol{A} \boldsymbol{S} \boldsymbol{A}$ : Naskah ditulis dalam bahasa Indonesia dengan ringkasan dalam bahasa Inggris atau dalam bahasa Inggris dengan ringkasan bahasa Indonesia.

FORMAT: Naskah diketik di atas kertas kuarto putih pada satu permukaan dengan 2 spasi. Pada semua tepi kertas disisakan ruang kosong minimal $3,5 \mathrm{~cm}$.

JUDUL : Judul dibuat tidak lebih dari 2 baris dan harus mencerminkan isi tulisan. Nama penulis dicantumkan di bawah judul.

RINGKASAN : Ringkasan dibuat tidak lebih dari 200 kata berupa intisari permasalahan secara menyeluruh, dan bersifat informatif mengenai hasil yang dicapai.

TABEL : Judul tabel dan keterangan yang diperlukan ditulis dalam bahasa Indonesia dan Inggris dengan jelas dan singkat. Tabel harus diberi nomor.

GAMBAR GARIS : Grafik dan ilustrasi lain yang berupa gambar garis harus kontras dan dibuat dengan tinta hitam. Setiap gambar garis harus diberi nomor, judul dan keterangan yang jelas dalam bahasa Indonesia dan Inggris.

FOTO : Foto harus mempunyai ketajaman yang baik, diberi judul dan keterangan seperti pada gambar.

DAFTAR PUSTAKA : Daftar pustaka yang dirujuk harus disusun menurut abjad nama pengarang dengan mencantumkan tahun penerbitan, seperti teladan berikut :

\section{NOTES FOR AUTHORS}

LANGUAGE : Manuscripts must be written in Indonesian with English summary or vice versa.

FORMAT: Manuscripts should be typed double spaced on one face of $\mathrm{A}_{4}$ white paper. A $3.5 \mathrm{~cm}$ margin should be left on all sides.

TITLE : Title must not exceed two lines, and should reflect the content of the manuscript. The author's name follows immediately under the title.

SUMMARY: Summary must not exceed 200 words, and should comprise informative essence of the entire content of the article.

$T A B L E$ : Title of tables and all necessary remarks must be written in Indonesian and English. Tables should be numbered.

LINE DRAWING : Graphs and other line drawing illustrations must be drawn in high contrast black ink. Each drawing must be numbered, titled and supplied with necessary remarks in Indonesia and English.

PHOTOGRAPH : Photographs submitted should have high contrast, and must be supplied with necessary information as in line drawing.

REFERENCE : References must be listed in alphabetical order of author's name with their year of publications as in the following example :

Allan, J.E. 1961. The determination of copper by atomic absorption spectrophotometry. Spectrochim. Acta, 17, $459-466$.

FAO. 1974. Logging and Log Transport in Tropical High Forest. FAO Forestry Development Paper No. 18, Rome.

Jane, F.W. 1955. The Structure of Wood. 1st ed. p. 328. London : Black. 


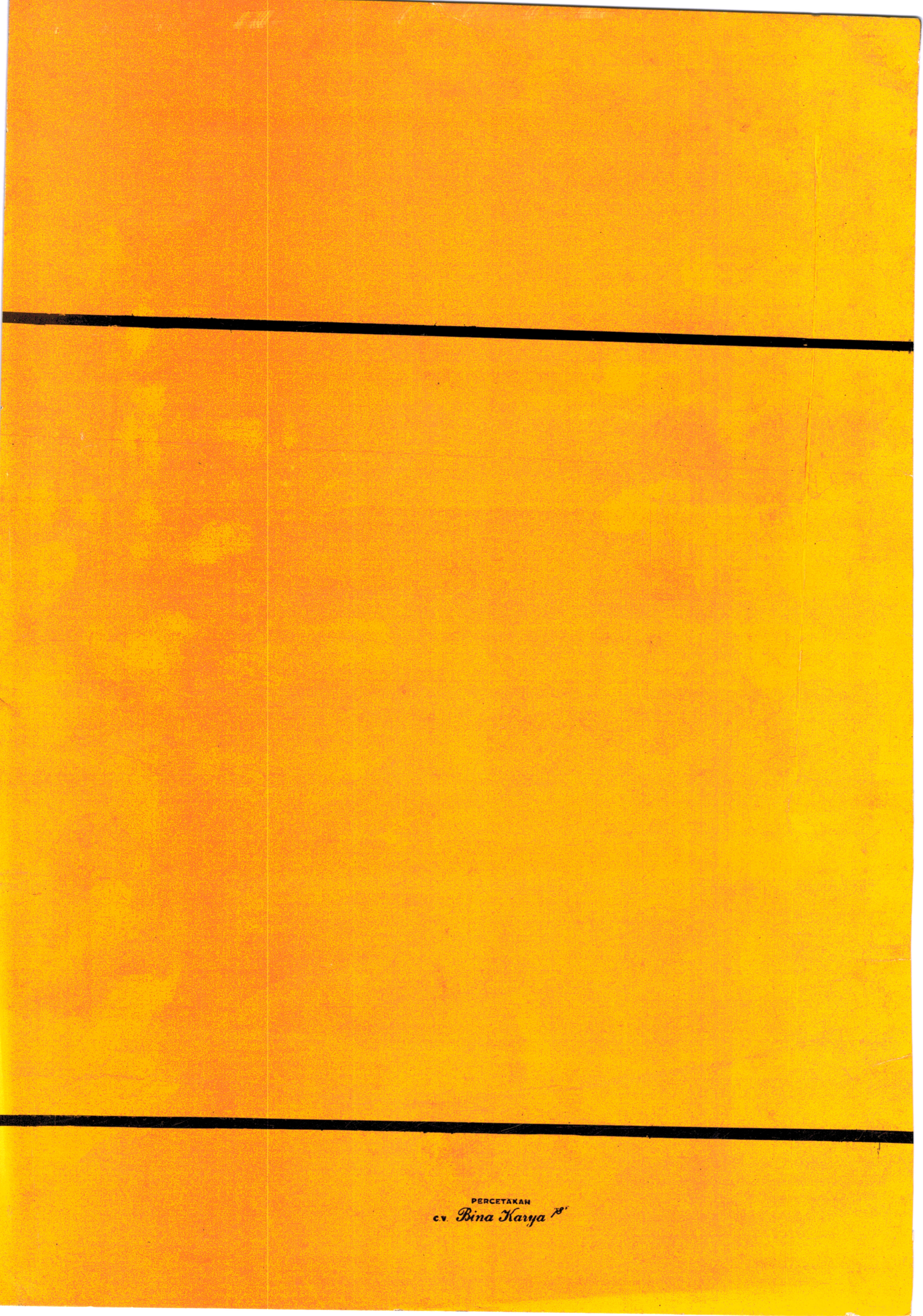

